\title{
Growth and grazing of a naked heterotrophic dinoflagellate, Gyrodinium dominans
}

\author{
Yasuo Nakamura ${ }^{1, *}$, Shin-ya Suzuki ${ }^{2}$, Juro Hiromi ${ }^{2}$ \\ ${ }^{1}$ National Institute for Environmental Studies, Tsukuba, Ibaraki 305, Japan \\ ${ }^{2}$ College of Agriculture and Veterinary Medicine, Nihon University, Setagaya, Tokyo 154, Japan
}

\begin{abstract}
Growth and grazing rates of a naked heterotrophic dinoflagellate, Gyrodinium dominans [equivalent spherical diameter $(E S D)=c a 20 \mu \mathrm{m}$ ), were examined in batch cultures. Strains isolated from the Seto Inland Sea (Harima strain) and Tokyo Bay (Tokyo strain) in Japan were used for the experiments. Both strains grew well when fed amorphous materials (such as bacterial flocs with attached nanoflagellates and aggregates of a small diatom) and plankton species with ESD of 15 to $26 \mu \mathrm{m}$. The Tokyo strain also grew rapidly when fed small (ca $5 \mu \mathrm{m}$ ) phytoplankton species at levels higher than $1 \times 10^{5} \mathrm{ml}^{-1}$ However, rates of ingestion of Nephroselmis aff, rotunda ( $\left.\mathrm{SD}=4.5 \mu \mathrm{m}\right)$ by the Tokyo strain were too low to sustain rapid growth of $G$. dominans at natural levels of small ( 2 to $8 \mu \mathrm{m})$ flagellate abundance $\left(<3 \times 10^{4} \mathrm{ml}^{-1}\right)$. Ingestion of Heterocapsa triquetra (ESD $\left.=15.3 \mu \mathrm{m}\right)$ followed Michaelis-Menten kinetics with half-saturation constants of 820 and $180 \mathrm{ml}^{-1}$ and maximum ingestion rates of 0.82 and 0.59 prey predator ${ }^{-1} \mathrm{~h}^{-1}$ for the Harima and Tokyo strains, respectively. The clearance rates of both strains feeding on $H$. triquetra were about 2 orders of magnitude higher than those for $N$ aff. rotunda. These results indicate that $G$. dominans can play an important role in the decline of red tides caused by large $(>15 \mu \mathrm{m})$ nanoflagellates such as Gymnodinium mikimotoi.
\end{abstract}

KEY WORDS: Grazing $\cdot$ Growth $\cdot$ Heterotrophic dinoflagellate $\cdot$ Microzooplankton $\cdot$ Red tide

\section{INTRODUCTION}

The importance of grazing by microzooplankton ( 20 to $200 \mu \mathrm{m}$ in size) on autotrophic and heterotrophic production has been discussed recently (e.g. Anderson 1988, Capriulo 1990). In some systems, microzooplankton herbivory could be more than 1 order of magnitude greater than copepod herbivory (Burkill et al. 1993). The major components of microzooplankton populations are planktonic ciliates and heterotrophic dinoflagellates. The trophic roles of ciliates have been studied extensively with special emphasis on their roles in the 'microbial loop' (e.g. Bernard \& Rassoulzadegan 1990, Verity 1991). However, although ecological information about heterotrophic dinoflagellates is now increasing (e.g. Lessard \& Swift 1985, Goldman et al. 1989, Hansen 1991, 1992, Strom 1991, Nakamura et al. 1992, Jacobson \& Anderson 1993, Strom \& Buskey

•E-mail: yasuo@nies.go.jp
1993, Verity et al. 1993), studies of this group with respect to abundance, succession, grazing and growth are still sparse in comparison with those on ciliates. Since the biomass of heterotrophic dinoflagellates is comparable to or in some cases exceeds that of ciliates in many planktonic ecosystems (Lessard 1991), trophic roles of this group should be evaluated in greater detail for a more complete understanding of carbon flow through microzooplankton populations.

Gyrodinium dominans Hulburt [equivalent spherical diameter $(E S D)=$ ca $20 \mu \mathrm{m}]$ is one of the most abundant heterotrophic dinoflagellates in the Seto Inland Sea (eutrophic) and Tokyo Bay (hypertrophic), Japan (H. Takayama \& M. Sato pers. comm.). The abundance of this species sometimes exceeds $100 \mathrm{ml}^{-1}$ just after red tides of Gymnodinium mikimotoi (ESD $=$ ca $15 \mu \mathrm{m}$ ) in the Seto Inland Sea (H. Takayama pers. comm.). Furthermore, during the period when abundance of small $(2$ to $8 \mu \mathrm{m})$ heterotrophic nanoflagellates (HNF) was rapidly decreasing in the Seto Inland Sea, 'G. 
dominans-like particles' were very often observed with epifluorescent microscopy of DAPI-stained seawater samples (Nakamura et al. 1994; not enumerated). These observations suggest that $G$. dominans is a potential predator for small $(<8 \mu \mathrm{m})$ as well as large $(>15 \mu \mathrm{m})$ nanoflagellates. Thus, there is a clear need to examine what kind of food $G$. dominans prefers and how fast it ingests prey and grows when supplied with different food concentrations. To these ends, we have established clonal cultures of $G$. dominans from the Seto Inland Sea and Tokyo Bay, and report here their growth and grazing rates under controlled conditions.

\section{MATERIALS AND METHODS}

Isolation and culture of Gyrodinium dominans. Clonal cultures of $G$. dominans were established by isolating a single cell from the surface seawater of Harima-nada, the Seto Inland Sea (Harima strain) and Tokyo Bay (Tokyo strain). The water temperatures of these sites during sampling were $25^{\circ} \mathrm{C}$ for the Harima strain and $23^{\circ} \mathrm{C}$ for the Tokyo strain. The Tokyo strain was kept in f/2 medium (Guillard \& Ryther 1962) with Thalassiosira sp. (see Table 1) as food. The Harima strain was initially maintained in $10 \mathrm{ml}$ of $\mathrm{N}_{1} \mathrm{P}$-reduced f $/ 2$ medium $\left(\mathrm{NO}_{3}{ }^{-}=100 \mu \mathrm{M}_{1} \mathrm{PO}_{4}{ }^{3-}=7 \mu \mathrm{M}\right.$; henceforth $\mathrm{f}^{*}$ medium) plus $0.5 \mathrm{ml}$ of STP medium (= dissolved organic C/N source; Provasoli et al. 1957) with Nephroselmis aff. rotunda $\left(>10^{5} \mathrm{ml}^{-1}\right.$; see Table 1$)$, HNF $\left(>10^{4} \mathrm{ml}^{-1}\right.$; species not identified, see Table 1$)$ and bacteria (rod, $>10^{7} \mathrm{ml}^{-1}$ ). The Harima strain fed on the bacterial flocs with attached algae and HNF which were formed in this 'medium' (henceforth P medium). Later, the Harima strain was kept in $\mathrm{f} / 2$ medium with Thalassiosira sp. as the Tokyo strain. Potential growth rate and food source experiments (below) for the Harima strain were conducted using cells grown in $\mathrm{P}$ medium. In other experiments, cells grown in $f / 2$ with Thalassiosira sp. were used. All cultures for both maintenance and experiments were kept in borosilicate test tubes $(18 \times 180 \mathrm{~mm})$ at $24 \pm 1^{\circ} \mathrm{C}$ with ca $100 \mu \mathrm{E} \mathrm{m} \mathrm{m}^{-2} \mathrm{~s}^{-1}$ under a $12 \mathrm{~h}$ light: $12 \mathrm{~h}$ dark cycle. Ingestion experiments (see below) were conducted during the light period. Cultures were rotated on a plankton wheel at $1 \mathrm{rpm}$ during the experiments of ingestion and growth dynamics as a function of prey concentration (see below) Otherwise, the cultures were not agitated.

Basic characteristics of Gyrodinium dominans. Species identifications of the Harima and Tokyo strains was conducted by $H$. Takayama under light microscope and SEM observations. Cells of the Harima and Tokyo strains in late exponential phase were $33.4 \pm 4.2$ $(\mathrm{n}=50)$ and $31.0 \pm 2.5 \mu \mathrm{m}(\mathrm{n}=50)$ in length and $4.8 \times$ $10^{3}$ and $4.0 \times 10^{3} \mu^{3}$ in volume, respectively. Epifluo- rescent microscope observations of the 2 strains clearly ruled out the presence of chloroplasts. In addition, intact cells of the Harima strain fluoresced bright green under blue light excitation while the Tokyo strain did not.

Both strains captured prey using a tow filament and prey was ingested through the flexible sulcas as Hansen (1992) observed in 3 Gyrodinium species.

In a previous study (Nakamura et al. 1992), we examined the growth and grazing of Gyrodinium 'dominans' (strain Gyro) feeding on the large prey Chattonella antiqua (see Table 1). Although the shape of strain Gyro was identical to the original description of $G$. dominans ( $H$. Inoue pers. comm.), Gyro (ca $60 \mu \mathrm{m}$ ) was much longer than the original description (18 to $43 \mu \mathrm{m}$ ). Unfortunately, the strain Gyro culture died 2 yr ago for uncertain reasons and SEM observations were not made. It is plausible that strain Gyro belonged to another species ( $\mathrm{H}$. Takayama pers. comm.).

Potential growth rate determination. Thirty-five tubes with $\mathrm{P}$ medium $(11.6 \mathrm{ml})$ or $\mathrm{f} / 2$ plus Thalassiosira sp. $\left(11 \mathrm{ml}\right.$, ca $\left.1 \times 10^{5} \mathrm{ml}^{-1}\right)$ were prepared. A $0.5 \mathrm{ml}$ volume of the maintenance culture of the Harima or Tokyo strain was inoculated into the tubes of $P$ medium or $\mathrm{f} / 2$ plus Thalassiosira $\mathrm{sp}$., respectively. Five tubes were taken daily and cell concentrations of Gyrodinium dominans were counted: samples were taken from each tube and $50 \mu \mathrm{l}$ of polyethylene oxide in filtered seawater $(1 \%)$ was added to the sample $(2 \mathrm{ml})$ to slow down the movement of $G$. dominans (Spoon et al. 1977). Then $1 \mathrm{ml}$ of the sample was counted in a Sedgewick-Rafter chamber under a light microscope. Growth rates were estimated as the slope of the linear portion of $\ln$ (Gyrodinium $\mathrm{ml}^{-1}$ ) regressed against time.

Growth experiments using different food sources. A set of experiments was conducted to determine the range of plankton species that would support growth of Gyrodinium dominans. Eighteen species of phytoplankton in 7 classes, 1 strain of bacteria and 1 strain of HNF with bacteria (see Table 1) were offered. The linear dimensions (length and width) of the prey cells were measured under microscopes, and cell volumes were calculated assuming simple geometric forms. For bacteria, Synechococcus sp. and HNF, cells were fixed, stained with DAPI (except for Synechococcus sp.), and observed under an epifluorescent microscope. For other prey, the linear dimensions of intact cells were measured under a light microscope. When phytoplankton species were the prey, $1 \mathrm{ml}$ of a dense culture of each species grown in $\mathrm{f} / 2$ was added to $10 \mathrm{ml}$ of $\mathrm{f}$. medium in test tubes. Ten cells of $G$. dominans washed 5 times in $\mathrm{f}^{*}$ were then introduced to each tube by micropipet and incubated for 4 or $5 \mathrm{~d}$. Our preliminary experiments showed that washing and isolation of the 
dinoflagellates did not affect their viability. After each incubation, $G$. dominans cells were counted as described above and the growth rate $(\mu)$ calculated as $\mu=\ln \left(N_{\mathrm{f}} / N_{\mathrm{i}}\right) / T$, where $T$ is the incubation time and $N_{\mathrm{i}}$ ( $\left.=0.91 \mathrm{ml}^{-1}\right)$ and $N_{\mathrm{f}}$ the initial and final concentrations of $G$. dominans, respectively. When bacteria was offered as prey, "STP $+\mathrm{f}$ "' medium was prepared by adding $0.5 \mathrm{ml}$ of STP medium to $10 \mathrm{ml}$ of $\mathrm{f}^{\bullet}$ medium, and $0.2 \mathrm{ml}$ of stock bacterial cultures was added. Then 10 cells of pre-washed $G$. dominans were inoculated to each tube, incubated and counted as above. In cases where HNF plus bacteria were the prey, HNF were precultured in STP $+\mathrm{f}^{*}$ medium for $2 \mathrm{~d}$ (HNF concentrations reached over $10^{5} \mathrm{ml}^{-1}$ ). Then 10 cells of prewashed $G$. dominans were introduced and their growth was followed as above. We also checked for the possibility of osmotrophic growth: 2 cells of $G$. dominans washed 7 times in $\mathrm{f}^{*}$ were introduced to $10.5 \mathrm{ml}$ of $\mathrm{STP}+\mathrm{f}^{*}$ medium and incubated for $7 \mathrm{~d}$. For each experiment, initial and final prey concentration were also determined.

For each prey, 3 to 10 tubes were used in each experiment and 2 to 4 independent experiments were conducted. In all experiments, growth of Gyrodinium dominans in $\mathrm{P}$ medium for the Harima strain or in $\mathrm{f}$. with Thalassiosira sp. for the Tokyo strain was examined as a control.

Ingestion experiments. Rates of ingestion of Nephroselmis aff. rotunda and Heterocapsa triquetra by Gyrodinium dominans were estimated by counting the number of ingested prey cells inside the predator cells after a known period of time (cf. Hansen 1992). Before determining the ingestion rates as a function of prey concentrations, we monitored the time course of ingestion. Twice-washed $G$. dominans were introduced by micropipet into 10 test tubes with $\mathrm{f}$ "medium (10 ml) to a final concentration of ca $30 \mathrm{ml}^{-1}$. N. aff. rotunda or $H$. triquetra were then added to each tube at concentrations of $1.5 \times 10^{5}$ or $3.5 \times 10^{3} \mathrm{ml}^{-1}$, respectively. The heterotrophic dinoflagellates were allowed to ingest $N$. aff. rotunda for $0.5,1$ and 2 h or $H$. triquetra for 1,2 and $3 \mathrm{~h}$ and were then fixed in glutaraldehyde (EM grade, final concentration $1 \%$ ). For each sampling period, 3 tubes were taken and 1 tube was used as a '0-time' sample. The fixed samples were stained with DAPI (final concentration $1 \mu \mathrm{g} \mathrm{ml}^{-1}$ ) and then filtered (vacuum pressure $<100 \mathrm{~mm} \mathrm{Hg}$ ) onto $0.8 \mu \mathrm{m}$ pore-size black Nuclepore filters ( $25 \mathrm{~mm}$ diameter). These filters were observed with a Nikon epifluorescent microscope under UV or blue-light excitation (Nakamura et al. 1994) at a magnification of $\times 500$. The number of vacuoles originating from $N$. aff. rotunda or $H$. triquetra inside each $G$. dominans cell was enumerated by monitoring the red autofluorescence of the vacuoles under blue-light excitation. At least $50 \mathrm{G}$. dominans

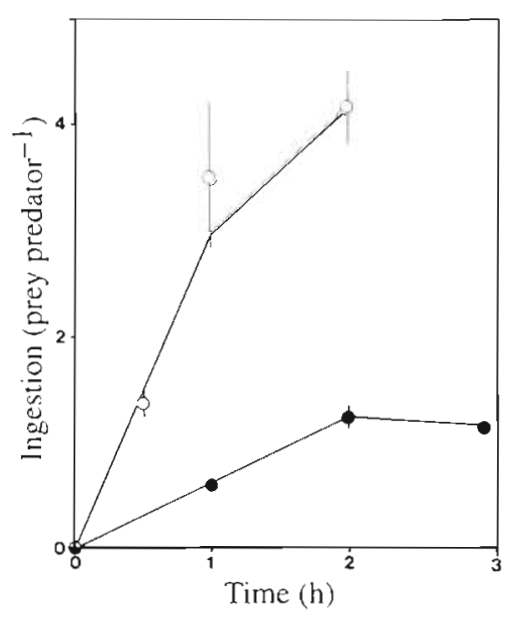

Fig. 1. Gyrodinium dominans (Tokyo strain). Number of particles inside predator cell clearly resembling (이 Nephroselmis aff. rotunda and $(\bullet)$ Heterocapsa triquetra as a function of incubation time. Error bars $= \pm 1 \mathrm{SD}$

cells were observed per sample. Although Hansen (1992) stated that algae lose their autofluorescence very quickly upon ingestion, this was not the case for $N$. aff. rotunda and $H$. triquetra ingested by $G$. dominans. The rates of ingestion of $N$. aff. rotunda and $H$. triquetra were constant during the first 1 or $2 \mathrm{~h}$ of incubation, respectively (Fig. 1). Therefore, an incubation time of $1 \mathrm{~h}$ was subsequently used in the experiments to estimate ingestion rates as a function of prey cell concentrations (see below).

Twice-washed Gyrodinium dominans were introduced to 15 test tubes with $\mathrm{f}^{*}(10 \mathrm{ml})$ at a concentration of ca $40 \mathrm{ml}^{-1}$. Nephroselmis aff. rotunda or Heterocapsa triquetra were added at 5 different concentrations ( 3 replicate tubes at each concentration). The ranges of the prey concentrations tested were $(0.1$ to 11) $\times 10^{4} \mathrm{ml}^{-1}$ for $N$. aff. rotunda and $(0.04$ to 6.2$) \times 10^{3}$ $\mathrm{ml}^{-1}$ for $H$. triquetra. The heterotrophic dinoflagellates were allowed to ingest the prey for $1 \mathrm{~h}$, then fixed, stained, filtered and observed under the epifluorescent microscope as described above. These experiments were repeated 3 times for each prey.

Rates of ingestion $(I)$ of Heterocapsa triquetra by the 2 Gyrodinium strains were fitted to the MichaelisMenten equation:

$$
I=I_{\max } \cdot N_{\text {prey }} /\left(K+N_{\text {prey }}\right)
$$

where $I_{\max }$ is the maximum ingestion rate, $K$ is the halfsaturation constant, and $N_{\text {prey }}$ is the prey concentration.

Growth rate dependence on prey concentration. Fifteen tubes of $\mathrm{f}^{*}(10 \mathrm{ml})$ were prepared and 40 cells of Gyrodinium dominans which had been washed 4 times were introduced into each tube. Heterocapsa tri- 
quetra were then added as prey at 5 different concentrations $\left[(0.04\right.$ to 3.9$\left.) \times 10^{3} \mathrm{ml}^{-1}\right]$ with 3 replicate tubes at each prey concentration. The tubes were incubated for $2 \mathrm{~d}$ and the final concentrations of $G$. dominans and $H$. triquetra were enumerated as described in 'potential growth rate determination'. The growth rates of G. dominans were calculated assuming exponential growth during incubation (see 'Growth experiments using different food sources').

Ingestion $(I)$ and growth rate $(\mu)$ data were interrelated by:

$$
\mu=G G E \cdot I\left(v_{\text {prey }} / V_{\text {pred }}\right)
$$

where GGE is the gross growth efficiency, and $v_{\text {prey }}$ and $v_{\text {pred }}$ are cell volumes of prey and predator, respectively.

\section{RESULTS}

\section{Potential growth rates}

Growth rates (with $95 \%$ confidence limits) of Gyrodinium dominans in $\mathrm{P}$ medium and $\mathrm{f} / 2$ with Thalassiosira sp. were $1.24(1.17,1.31)$ and $1.36(1.28,1.44)$

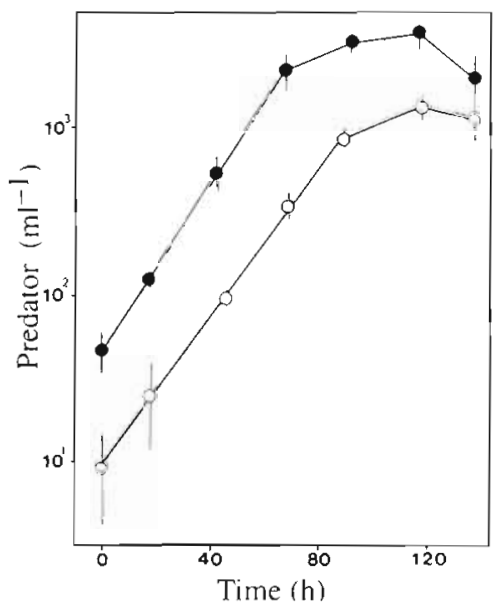

Fig. 2. Gyrodinium dominans. Growth curves for (o) the Harima strain in $\mathrm{P}$ medium and $(\bullet)$ the Tokyo strain fed Thalassiosira sp. Error bars $= \pm 1 \mathrm{SD}$

$\mathrm{d}^{-1}$ for the Harima and Tokyo strains, respectively (Fig. 2). Changes in $G$. dominans cell size were not apparent during the exponential growth period but small cells of ca $20 \mu \mathrm{m}$ in length appeared during the stationary and senescent period. However, the fraction

Table 1. Gyrodinium dominans. Growth using different food sources. ESD: equivalent spherical diameter; $I N_{\text {prey: }}$ initial prey concentration; $\mu$ : growth rate; $n$ : total number of cultures examined. Classes: $C_{y}$, Cyanophyceae; Ch, Chlorophyceae; Pry, Prymnesiophyceae; Pra, Prasinophyceae; D, Dinophyceae; R, Raphidophyceae; B, Bacillariophyceae. If final cell concentration of $G$. dominans was below $1 \mathrm{ml}^{-1}, 0.0 \mathrm{~d}^{-1}$ was assumed for the growth rate

\begin{tabular}{|c|c|c|c|c|c|c|c|}
\hline \multirow[t]{2}{*}{ Food (Class) } & \multirow[t]{2}{*}{$\mathrm{ESD}(\mu \mathrm{m})$} & \multirow[t]{2}{*}{ Remarks } & \multirow[t]{2}{*}{$I N_{\text {prey }}$} & \multicolumn{2}{|c|}{ Harima strain } & \multicolumn{2}{|c|}{ Tokyo strain } \\
\hline & & & & $n$ & $\mu \pm \mathrm{SD}\left(\mathrm{d}^{-1}\right)$ & $\mathrm{n}$ & $\mu \pm \operatorname{SD}\left(d^{-1}\right)$ \\
\hline STP medium & & DOC and DON & & 19 & $0.00 \pm 0.00$ & 8 & $0.00 \pm 0.00$ \\
\hline STP + bacteria & 1.2 & Rod & $(3-5) \times 10^{7}$ & 16 & $0.00 \pm 0.00$ & 8 & $0.00 \pm 0.00$ \\
\hline Synechococcus sp. ${ }^{a}(\mathrm{Cy})$ & 1.3 & & $(0.6-1) \times 10^{7}$ & 6 & $0.00 \pm 0.00$ & 8 & $0.00 \pm 0.00$ \\
\hline Chlorella capsulata (Ch) & 4.2 & & $(2-4) \times 10^{5}$ & 6 & $0.00 \pm 0.00$ & 7 & $0.59 \pm 0.10$ \\
\hline Isochrysis galbana (Pry) & 4.2 & & $(2-5) \times 10^{5}$ & 11 & $0.14 \pm 0.14$ & 7 & $0.70 \pm 0.09$ \\
\hline Nephroselmis aff. rotunda (Pra) & 4.5 & & $(1-2) \times 10^{5}$ & 18 & $0.19 \pm 0.22$ & 7 & $0.79 \pm 0.08$ \\
\hline Gephyrocapsa oceanica ${ }^{\text {(Pry) }}$ & 4.7 & & $2 \times 10^{5}$ & 5 & $0.03 \pm 0.07$ & 7 & $0.64 \pm 0.10$ \\
\hline Amphidinium carterae (D) & 8.4 & Naked & $(3-7) \times 10^{3}$ & 10 & $0.05 \pm 0.08$ & 9 & $0.45 \pm 0.20$ \\
\hline Pyramimonas parkeae (Pra) & 10.5 & & $(1-2) \times 10^{4}$ & 7 & $0.03 \pm 0.07$ & 8 & $0.10 \pm 0.10$ \\
\hline Heterosigma akashiwo d (R) & 10.6 & & $(1-3) \times 10^{4}$ & 16 & $0.05 \pm 0.09$ & 9 & $0.23 \pm 0.19$ \\
\hline Heterocapsa triquetra ${ }^{\mathrm{d}}$ (D) & 15.3 & Thecate & $(4-9) \times 10^{3}$ & 8 & $0.62 \pm 0.20$ & 7 & $0.81 \pm 0.08$ \\
\hline Scrippsiella trochoidea ${ }^{d}(\mathrm{D})$ & 16.3 & Thecate & $(1-2) \times 10^{3}$ & 10 & $0.04 \pm 0.10$ & 7 & $0.55 \pm 0.10$ \\
\hline Gymnodinium mikimotoi ${ }^{a}$ (D) & 16.8 & Naked & $(1-2) \times 10^{3}$ & 5 & $0.40 \pm 0.16$ & 9 & $0.73 \pm 0.14$ \\
\hline Prorocentrum micans ${ }^{a}$ (D) & 24.3 & Thecate & $(1-2) \times 10^{3}$ & 10 & $0.00 \pm 0.00$ & 7 & $0.11 \pm 0.14$ \\
\hline Chattonella marina $(\mathrm{R})$ & 26.3 & & $(2-3) \times 10^{3}$ & 7 & $0.39 \pm 0.12$ & 7 & $0.69 \pm 0.10$ \\
\hline Chattonella antiqua ${ }^{2}(\mathrm{R})$ & 35.3 & & $(1-2) \times 10^{3}$ & 8 & $0.12 \pm 0.18$ & 8 & $0.05 \pm 0.09$ \\
\hline Thalassiosira sp. (B) & 5.4 & $1-10$ cells colony ${ }^{-1}$ & $(1-4) \times 10^{5}$ & 25 & $0.98 \pm 0.30$ & 23 & $1.10 \pm 0.13$ \\
\hline Skeletonema costatum ${ }^{\mathrm{d}}(\mathrm{B})$ & 5.6 & $4-10$ cells chain ${ }^{-1}$ & $(1-4) \times 10^{5}$ & 8 & $0.00 \pm 0.00$ & 8 & $0.37 \pm 0.13$ \\
\hline Asterionella glacialis $(B)$ & 7.8 & $2-4$ cells colony ${ }^{-1}$ & $(1-2) \times 10^{4}$ & 8 & $0.00 \pm 0.00$ & 8 & $0.00 \pm 0.00$ \\
\hline Chaetoceros sociale (B) & 8.3 & $2-8$ cells chain ${ }^{-1}$ & $(1-2) \times 10^{4}$ & 8 & $0.00 \pm 0.00$ & 8 & $0.00 \pm 0.00$ \\
\hline $\mathrm{STP}+$ bacteria $+\mathrm{HNF}$ & 2.0 & Bacteria floc & $(1-2) \times 10^{5}$ & 21 & $0.00 \pm 0.00$ & 8 & $0.00 \pm 0.00$ \\
\hline P medium & & Bacteria floc & & 63 & $0.91 \pm 0.16$ & 9 & $0.82 \pm 0.10$ \\
\hline${ }^{a}$ Axenic strain & & & & & & & \\
\hline
\end{tabular}


of small cells differed from tube to tube (20 to $80 \%)$. Prey cell concentrations during the stationary phase $\left(120 \mathrm{~h}\right.$ after inoculation; Fig. 2) were $2 \times 10^{7} \mathrm{ml}^{-1}$ (bacteria), $3 \times 10^{5} \mathrm{ml}^{-1}(\mathrm{HNF})$ and $2 \times 10^{5} \mathrm{ml}^{-1}$ (Nephroselmis aff. rotunda) for the Harima strain and $1 \times 10^{6} \mathrm{ml}^{-1}$ (Thalassiosira sp.) for the Tokyo strain.

\section{Growth experiments using different food sources}

Experiments on the growth of Gyrodinium dominans supplied with different food sources revealed some tendencies with respect to food utilization in the Harima and Tokyo strains (Table 1). First, both strains prefer amorphous materials such as bacterial flocs with attached flagellates formed in $\mathrm{P}$ medium and loose colonies of a small diatom (Thalassiosira sp.). Second, they are not osmotrophic and could not utilize picosized particles such as heterotrophic bacteria or Synechococcus sp. Third, chain forming diatoms (Skeletonema costatum, Chaetoceros sociale) and some dinoflagellates (Scrippsiella trochoidea, Prorocentrum micans) were not suitable food sources. Fourth, particles with ESD comparable to that of $G$. dominans
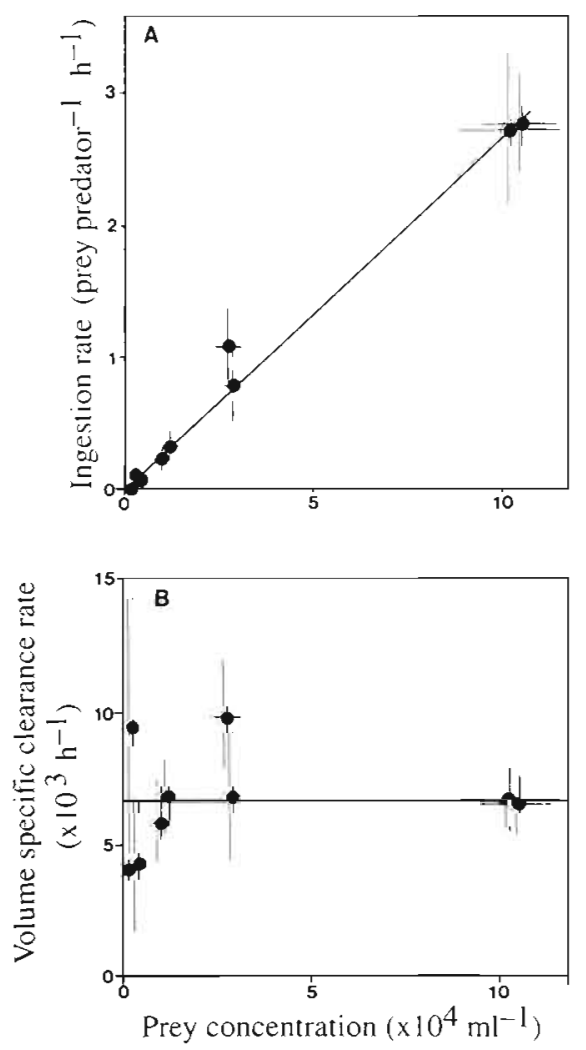

Fig. 3. Gyrodinium dominans (Tokyo strain) fed Nephroselmis aff. rotunda. (A) Ingestion rate and (B) volume-specific clearance rate as functions of prey concentration. Error bars $= \pm 1 \mathrm{SD}$ (i.e. Heterocapsa triquetra, Gymnodinium mikimotoi. Chattonella marina; $\mathrm{ESD}=15$ to $26 \mu \mathrm{m}$ ) served as good food sources. Fifth, $G$. dominans could not effectively utilize large particles with ESD 1.7 times larger than itself. These characteristics are common for both the Harima and Tokyo strains. However, significant strain differences were observed with respect to the utilization of particles less than $12 \mu \mathrm{m}$. When particles with ESD less than $12 \mu \mathrm{m}$ were used as prey, the growth of the Harima strain was very poor. On the contrary, the growth rates of the Tokyo strain fed with particles with ESD of ca $5 \mu \mathrm{m}$ were high and comparable to those for particles with ESD of ca $20 \mu \mathrm{m}$.

\section{Ingestion}

Rates of ingestion of Nephroselmis aff, rotunda (ESD $=4.5 \mu \mathrm{m})$ by the Tokyo strain increased linearly with prey concentration (Fig. 3A) and reached ca 3 prey predator ${ }^{-1} \mathrm{~h}^{-1}$ at a prey level of $1 \times 10^{5} \mathrm{ml}^{-1}$. Volume specific clearance rate (VSC) is defined as:

$$
V S C=I /\left(N_{\text {prey }} \cdot V_{\text {pred }}\right)
$$

where $I$ is the ingestion rate, $N_{\text {prey }}$ is the prey concentration and $v_{\text {pred }}$ is the cell volume of predator VSC was independent of prey cell concentration and was about $6 \times 10^{3} \mathrm{~h}^{-1}$ (Fig. 3B).

Rates of ingestion of Heterocapsa triquetra (ESD = $15.3 \mu \mathrm{m})$ by the Tokyo and Harima strains increased hyperbolically with prey cell concentrations (Figs. 4A $\& 5 \mathrm{~A}$ ) and were fitted to Eq. (1). The calculated $I_{\max }$ and $K$ values were 0.59 prey predator ${ }^{-1} \mathrm{~h}^{-1}$ and $1.8 \times 10^{2}$ $\mathrm{ml}^{-1}$, respectively, for the Tokyo strain and 0.82 prey predator ${ }^{-1} \mathrm{~h}^{-1}$ and $8.2 \times 10^{2} \mathrm{ml}^{-1}$, respectively for the Harima strain. VSC decreased with prey concentrations (Figs. $4 \mathrm{~B} \& 5 \mathrm{~B}$ ) and was on the order of $10^{5} \mathrm{~h}^{-1}$.

\section{Growth rates as a function of prey cell concentrations}

The growth rate of the Tokyo strain increased with prey concentration (Fig. 6). Negative growth was observed when the initial prey concentration $\left(I N_{\text {prey }}\right)$ was $36 \mathrm{ml}^{-1}$. The growth rate was ca $0.5 \mathrm{~d}^{-1}$ at $I N_{\text {prey }}$ of $1 \times 10^{2} \mathrm{ml}^{-1}$ and reached a plateau (ca $0.8 \mathrm{~d}^{-1}$ ) at $I N_{\text {prey }}$ higher than $4 \times 10^{2} \mathrm{ml}^{-1}$.

\section{DISCUSSION}

The growth rates of Gyrodinium dominans feeding on bacterial flocs in $\mathrm{P}$ medium or amorphous aggregates of Thalassiosira sp. (Fig. 2) far exceeded those of autotrophic dinoflagellates ( $<0.69 \mathrm{~d}^{-1}$; Loeblich 1967) 

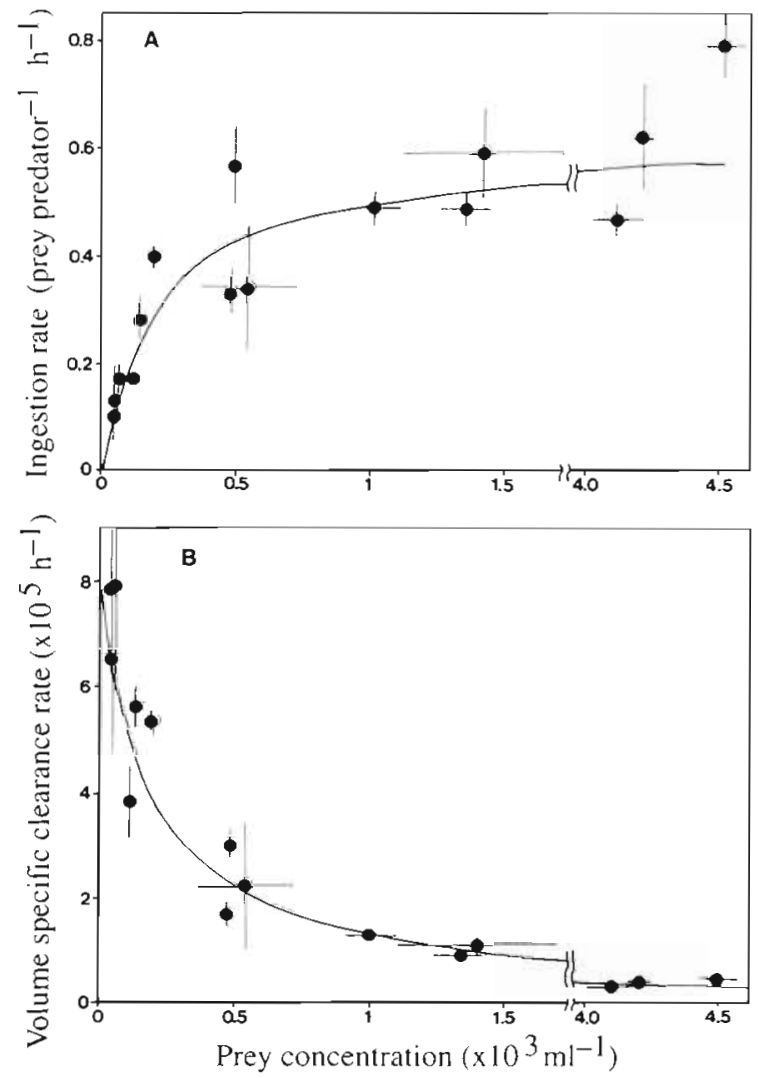

Fig. 4. Gyrodinium dominans (Tokyo strain) fed Heterocapsa triquetra. (A) Ingestion rate and (B) volume-specific clearance rate as functions of prey concentration. Curves numerically fitted to Michaelis-Menten kinetics. Error bars $= \pm 1 \mathrm{SD}$

and are, in fact, the highest rates ever recorded for heterotrophic dinoflagellates in culture 10.3 to $1.2 \mathrm{~d}^{-1}$; Hansen 1992, Jacobson \& Anderson 1993). However, it should be noted that most of the previous heterotrophic dinoflagellate growth experiments were conducted at or below $20^{\circ} \mathrm{C}$, while our results were obtained at $24^{\circ} \mathrm{C}$. If we assume a $Q_{10}$ of 2.5 (Fenchel \& Finlay 1983), then the growth rate of Gyrodinium spirale (Hansen 1992) adjusted to $24^{\circ} \mathrm{C}$ would be $1.2 \mathrm{~d}^{-1}$, comparable to that for $G$. dominans.

In the growth experiments using different food sources, the culture tubes were not rotated and even distribution of prey was not attained. Under non-agitated conditions, chain forming diatoms such as Skeletonema costatum and Chaetoceros sociale fell to the bottom of the experimental tubes and this might have made it impossible for $G$. dominans to catch the prey, leading to a poor growth of the predator (Table 1).

Both strains of Gyrodinium dominans grew well when fed bacterial flocs with attached algae and HNF formed in $\mathrm{P}$ medium. In contrast, no growth was observed with 'HNF + bacteria' (Table 1) where bacter-
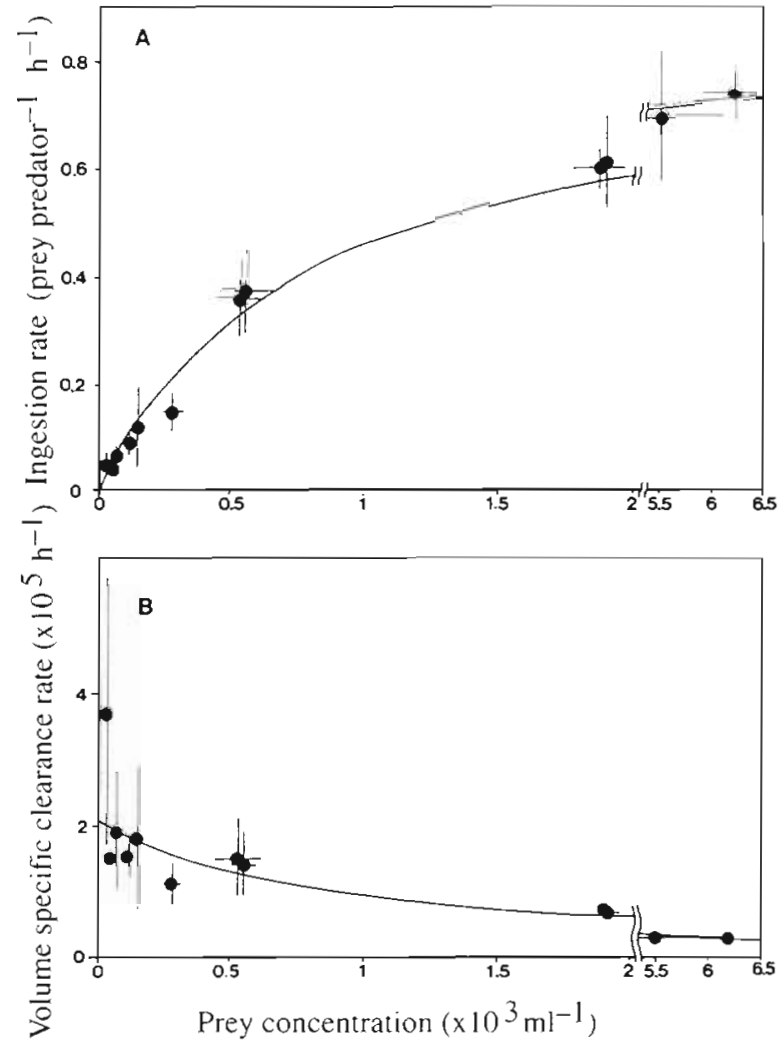

Fig. 5. Gyrodinium dominans (Harima strain) fed Heterocapsa triquetra. (A) Ingestion rate and (B) volume-specific clearance rate as functions of prey concentration. Curves numerically fitted to Michaelis-Menten kinetics. Error bars $= \pm 1 \mathrm{SD}$

ial flocs with attached HNF were formed. This is probably because $\mathrm{NH}_{4}{ }^{+}$regenerated by bacterivory of HNF caused toxic effects on $G$. dominans in the 'HNF + bacteria' treatment while $\mathrm{NH}_{4}{ }^{+}$was taken up by the algae in the P medium.

Large strain differences between the Harima and Tokyo strains of Gyrodinium dominans were observed with respect to suitable food sources: the former prefers particles with ESD of 15 to $26 \mu \mathrm{m}$ while the latter grows well when feeding on particles with ESD of $5 \mu \mathrm{m}$ as well as 15 to $26 \mu \mathrm{m}$ (Table 1). However, the clearance rates of the Tokyo strain feeding on Nephroselmis aff. rotunda (ESD $=4.5 \mu \mathrm{m}_{\mathrm{i}}$ Fig $3 \mathrm{~B}$ ) are about 2 orders of magnitude lower than those for Heterocapsa triquetra $\left(\mathrm{ESD}=15.3 \mu \mathrm{m}_{\mathrm{i}}\right.$ Fig. $\left.4 \mathrm{~B}\right)$, indicating that the Tokyo strain utilizes the larger prey more effectively than the smaller one.

In Tokyo Bay, the abundance of small (2 to $8 \mu \mathrm{m}$ ) flagellates sometimes reaches $3 \times 10^{4} \mathrm{ml}^{-1}$ (Nakamura unpubl.). At this level the calculated growth rate of the Tokyo strain by Eq. (2) assuming GGE of 0.6 (the highest value reported for heterotrophic dinoflagellates; Strom \& Buskey 1993) would be $0.14 \mathrm{~d}^{-1}$, making it dif- 
Table 2. Ingestion parameters for various species of heterotrophic dinoflagellates. $K_{C}$ : carbon-based half-saturation constant; $I^{*}{ }_{\max }$ : volume-specific maximum ingestion rate; $V S C_{\max }$ : volume-specific maximum clearance rate. A carbon/volume conversion factor of $0.14 \mathrm{pg} \mathrm{C} \mathrm{mm}^{-3}$ was assumed (Lessard 1991)

\begin{tabular}{|c|c|c|c|c|c|c|}
\hline Predator & $\begin{array}{c}\text { Temp. } \\
\left({ }^{\circ} \mathrm{C}\right)\end{array}$ & Prey & $\begin{array}{c}K_{\mathrm{C}} \\
\left(\mu \mathrm{g}^{-1}\right)\end{array}$ & $\begin{array}{l}I^{*} \max \\
\left(\mathrm{h}^{-1}\right)\end{array}$ & $\begin{array}{c}V_{S C} C_{\max } \\
\left(\mathrm{h}^{-1}\right)\end{array}$ & Source \\
\hline \multicolumn{7}{|l|}{ Gyrodinium dominans } \\
\hline Harima strain & 24 & Heterocapsa triquetra & 220 & 0.32 & $2.1 \times 10^{5}$ & This study \\
\hline Tokyo strain & 24 & Heterocapsa triquetra & 50 & 0.28 & $8.0 \times 10^{5}$ & This study \\
\hline Gyrodinium spirale & 15 & Heterocapsa triquetra & 560 & 0.14 & $3.4 \times 10^{4}$ & Hansen (1992) \\
\hline Oblea rotunda & 20 & Ditylum brightwellii & 250 & 0.07 & $1.1 \times 10^{5}$ & Strom \& Buskey (1993) \\
\hline Protoperidinium hirobis & 20 & Leptocylindrus danicus & 160 & 0.38 & $7.8 \times 10^{4}$ & Jacobson \& Anderson (1993) \\
\hline
\end{tabular}

ficult for Gyrodinium dominans to sustain its population in the field by ingesting small flagellates alone. The impact of $G$. dominans grazing on small flagellates $\left(\mathrm{d}^{-1}\right)$ is calculated by:

$$
I \cdot N_{\text {pred }} / N_{\text {prey }}=6.3 \times 10^{-4} N_{\text {pred }}
$$

At $N_{\text {pred }}$ of $100 \mathrm{ml}^{-1}$, close to the maximum observed in Tokyo Bay (M. Sato pers. comm.), only $6.3 \%$ of small flagellate population would be grazed per day. Therefore, we conclude that $G$. dominans does not play an important role in controlling the natural populations of small flagellates there, and further that natural levels of the small flagellates are insufficient to support the rapid growth of $G$. dominans.

In order to compare the ingestion data for Gyrodinium dominans with those for other heterotrophic dinoflagellates, carbon-based half-saturation constants $\left(K_{C}\right)$, volume-specific maximum ingestion rates $\left[I^{*}{ }_{\text {max }}=\right.$ $\left.I_{\max } \cdot\left(V_{\text {prey }} / V_{\text {pred }}\right)\right)$, and volume-specific maximum clearance rates $\left[V S C_{\max }=I_{\max } /\left(K \cdot v_{\text {pred }}\right)\right]$ were calculated (Table 2). The $K_{C}$ values for the $G$. dominans strains fed Heterocapsa triquetra are lower or comparable to and the $I^{*}$ max and $V S C_{\max }$ values are higher or comparable to those for other species, indicating that $G$. dominas is a potential predator for large $(>15 \mu \mathrm{m})$ nanoflagellates.

The growth rate of a predator as a function of prey (phytoplankton) concentration is usually determined under dim light and at low predator concentration to minimize the changes in prey concentration during the experiment. We tried repeatedly to establish the above relationship under dim light (ca $5 \mu \mathrm{E} \mathrm{m}^{-2} \mathrm{~s}^{-1}$, $24 \mathrm{~h}$ light: $0 \mathrm{~h}$ dark). However, the growth rates obtained were unusually low $\left(<0.2 \mathrm{~d}^{-1}\right)$, the prey (Heterocapsa triquetra) looked unhealthy and accumulated at the bottom of culture tubes. We also tried to culture under high-light $\left(100 \mu \mathrm{E} \mathrm{m}^{-2} \mathrm{~s}^{-1}, 24 \mathrm{~h}\right.$ light: $0 \mathrm{~h}$ dark) conditions but these experiments also failed: negative growth and unhealthy prey at the bottom. So we examined the relationship under 'usual' conditions (100 $\mu \mathrm{E} \mathrm{m}^{-2} \mathrm{~s}^{-1}, 12 \mathrm{~h}$ light: $12 \mathrm{~h}$ dark). Under these conditions, the prey concentrations changed significantly (Fig. 6), the prey were not distributed uniformly at night and thus the results obtained are somewhat qualitative. However, it should be noted that the Tokyo strain of Gyrodinium dominans grew at a rate of $0.5 \mathrm{~d}^{-1}$ (ca $60 \%$ of the maximum) when the initial prey concentration was $1 \times 10^{2} \mathrm{ml}^{-1}$ (Fig. 6). On the contrary, $G$. spirale fed $H$. triquetra could not sustain growth when the prey concentration was below $1 \times 10^{3} \mathrm{ml}^{-1}$ (Hansen 1992). Thus $G$. dominans seems to be adapted to lower prey concentration than G. spirale.

In the Seto Inland Sea, red tides of Gymnodinium mikimotoi $(\mathrm{ESD}=16.8 \mu \mathrm{m})$ occur during the warm season and the decline of these red tides is often coupled to increases in the abundance of Gyrodinium dominans (Nakamura et al. 1995, H. Takayama pers. comm.). Assuming that the rate of ingestion of $G$. mikimotoi by $G$. dominans is comparable to that of Heterocapsa triquetra $(\mathrm{ESD}=15.3 \mu \mathrm{m})$ by the Harima strain, the grazing impact $\left(\mathrm{d}^{-1}\right)$ on the red tide population is

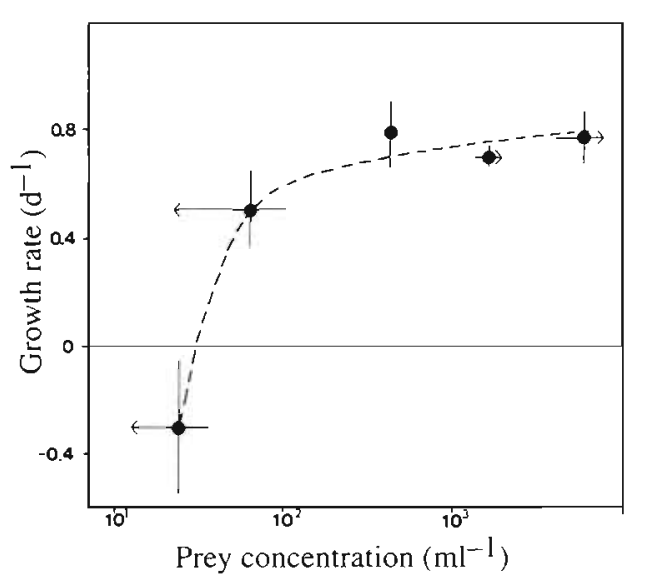

Fig. 6. Gyrodinium dominans (Tokyo strain) fed Heterocapsa triquetra. Growth rate as a function of prey concentration. Horizontal arrows indicate prey concentrations (from initial to final). Error bars $= \pm 1 \mathrm{SD}$ 
calculated as:

$$
I \cdot N_{\text {pred }} / N_{\text {prey }}=20 N_{\text {pred }} /\left(820+N_{\text {prey }}\right)
$$

At $N_{\text {prey }}$ of $5 \times 10^{2} \mathrm{ml}^{-1}$ and $N_{\text {pred }}$ of 10 to $30 \mathrm{ml}^{-1}$ (typical cell concentrations during the red tide in 1994; Nakamura et al. 1995), 15 to $45 \%$ of the G. mikimotoi standing crop is grazed per day, indicating that $G$. dominans plays important role in the disappearance of $G$. mikimotoi red tides. In contrast, before the outbreak of G. mikimotoi, the abundance of particles with ESD around $20 \mu \mathrm{m}$ (mainly composed of $G$. mikimotoi and Chattonella marina) was ca $10 \mathrm{ml}^{-1}$ (Nakamura et al. $1995)$ and $G$. dominans does not seem to sustain growth using such particles alone. Perhaps $G$. dominans ingests amorphous materials such as bacterial flocs and organic aggregates to survive under unfavorable conditions.

Acknowledgements. We thank Dr H. Takayama for SEM observations, species identification and helpful comments; $\mathrm{Dr}$ M. Sato for making his field data available; and Dr R. Weisburd for his constructive comments and linguistic corrections. This study was supported by a Grant-in-Aid No. 05640720 from the Scientific Research Fund of the Ministry of Education, Science and Culture, Japan.

\section{LITERATURE CITED}

Anderson OR (1988) Comparative protozoology. Springer, New York

Bernard C, Rassoulzadegan F (1990) Bacteria or microflagellates as a major food source for marine ciliates: possible implications for the microzooplankton. Mar Ecol Prog Ser 64:147-155

Burkill PH, Edwards ES, John AWG, Sleigh MA (199.3) Microzooplankton and their herbivorous activity in the northeastern Atlantic Ocean. Deep Sea Res II 40:479-493

Capriulo GM (1990) Ecology of marine protozoa. Oxford University Press, New York

Fenchel T, Finlay BJ (1983) Respiration rates in heterotrophic free-living Protozoa. Microb Ecol 9:99-122

Goldman JC, Dennett MR, Gordin H (1989) Dynamics of herbivorous grazing by the heterotrophic dinoflagellate Oxyrrhis marina. J Plankton Res 11:391-407

Guillard RRL, Ryther RH (1962) Studies of marine planktonic diatoms. 1. Cyclotella nana Hustedt and Detonula confervacea (Cleve) Gran. Can J Microbiol 8:229-239

Hansen PJ (1991) Quantitative importance and trophic role of heterotrophic dinoflagellates in a coastal pelagial food web. Mar Ecol Prog Ser 73:253-261

Hansen PJ (1992) Prey size selection, feeding rates and growth dynamics of heterotrophic dinoflagellates with special emphasis on Gyrodinium spirale. Mar Biol 114 : $327-334$

Jacobson DM, Anderson DM (1993) Growth and grazing rates of Protoperidinium hirobis Abé, a thecate heterotrophic dinoflagellate. J Plankton Res 15:723-736

Lessard EJ (1991) The role of heterotrophic dinoflagellates in diverse environments. Mar microb Food Webs 5:49-58

Lessard EJ, Swift E (1985) Species-specific grazing rates of heterotrophic dinoflagellates in oceanic waters, measured with a dual label radioisotope technique. Mar Biol 87: 289-296

Loeblich AR III (1967) Aspects of the physiology and biochemistry of the Pyrrophyta. Phykos 5:216-255

Nakamura Y, Fukami K, Sasaki S, Hiromi J (1994) Population dynamics of bacteria and heterotrophic nanoflagellates following the summer diatom bloom in the Seto Inland Sea. Bull Plankton Soc Japan 41:1-8

Nakamura Y, Suzuki S, Hiromi J (1995) Population dynamics of heterotrophic dinoflagellates during a Gymnodinium mikimotoi red tide in the Seto Inland Sea. Mar Ecol Prog Ser (in press)

Nakamura Y, Yamazaki Y, Hiromi J (1992) Growth and grazing of a heterotrophic dinoflagellate, Gyrodinium dominans, feeding on a red tide flagelllate, Chattonella antiqua. Mar Ecol Prog Ser 82:275-279

Provasoli L, McLaughlin JJA, Droop MR (1957) The development of artificial media for marine algae. Arch Mikrobiol 25:392-4:28

Spoon DM, Feise CO II, Youn RS (1977) Poly(ethylene oxide), a new slowing agent for Protozoa. J Protozool 24:471-474

Strom SL (1991) Growth and grazing rates of the herbivorous dinoflagellate Gymnodinium sp. from the open subarctic Pacific Ocean. Mar Ecol Prog Ser 78:103-113

Strom SL, Buskey EJ (1993) Feeding, growth, and behavior of the thecate heterotrophic dinoflagellate Oblea rotunda. Limnol Oceanogr 38:965-977

Verity PG (1991) Measurement and simulation of prey uptake by marine planktonic ciliates fed plastidic and aplastidic nanoplankton. Limnol Oceanogr 36:729-750

Verity PG, Stoecker DK, Sieracki ME, Burkill PH, Edwards ES, Tronzo CR (1993) Abundance, biomass and distribution of heterotrophic dinoflagellates during the North Atlantic spring bloom. Deep Sea Res II 40:227-244 